\title{
Profil Kawasan Reboisasi Mangrove Kepulauan Seribu Berdasarkan Karakteristik Lingkungan dan Fauna Makrobentik Terkait
}

\author{
Mangrove Reboisation Area Profile of Seribu Island Based on Environmental \\ Characteristics and Related Macrobenthic Fauna
}
Febrianti Lestari $^{1}$, Syahrial ${ }^{2 *}$, Rika Anggraini ${ }^{1}$, Yudho Andika ${ }^{2}$, Cut Meurah Nurul 'Akla², Agus Putra Abdul Samad ${ }^{3}$

\author{
${ }^{1}$ Jurusan Ilmu Kelautan, Fakultas Ilmu Kelautan dan Perikanan, Universitas Maritim Raja Ali Haji, \\ Kepulauan Riau, Indonesia \\ ${ }^{2}$ Program Studi Ilmu Kelautan, Fakultas Pertanian, Universitas Malikussaleh, Aceh, Indonesia \\ ${ }^{3}$ Program Studi Budidaya Perairan, Fakultas Pertanian, Universitas Samudra, Aceh, Indonesia \\ *Korespondensi: syahrial.marine@unimal.ac.id
}

\begin{abstract}
ABSTRAK
Fauna makrobentik sering digunakan sebagai bioindikator kualitas lingkungan dan informasi tentang karakteristik lingkungan maupun keberadaan fauna makrobentik di kawasan reboisasi mangrove masih sangat terbatas. Kajian profil kawasan reboisasi mangrove Kepulauan Seribu berdasarkan karakteristik lingkungan dan fauna makrobentiknya telah dilakukan pada bulan Maret 2014. Kajian ini bertujuan untuk mengetahui kondisi ekologi perairan di sekitar kawasan reboisasi mangrove Kepulauan Seribu. Untuk mengetahui keterkaitan karakteristik lingkungan dan fauna makrobentik dengan stasiun pengamatan dilakukan dengan statistik Correspondence Analysis (CA), sedangkan karakteristik lingkungan penentu fauna makrobentik serta hubungannya dilakukan dengan statistik Principal Component Analysis (PCA) dan regresi linier sederhana. Hasil kajian memperlihatkan bahwa konsentrasi karakteristik lingkungan yang diukur tidak begitu berbeda antar stasiun dan tidak melebihi ambang baku mutu untuk kehidupan biota laut. Selanjutnya fauna makrobentik yang ditemukan terdiri dari 6 spesies dengan kepadatan tertingginya berada di Stasiun $3\left(05.00 \mathrm{ind} / \mathrm{m}^{2}\right)$ dan terendahnya di Stasiun $1\left(02.00 \mathrm{ind} / \mathrm{m}^{2}\right)$. Pada Stasiun 1 konsentrasi $\mathrm{pH}$ dan suhunya sangat tinggi, sedangkan Stasiun 2 dan 3 konsentrasi salinitasnya yang tinggi. Fauna makrobentik Atilia (Columbella) scripta, Metopograpsus latifrons, Littoraria scabra, Saccostrea cucculata dan Cardisoma carnifex dapat berasosiasi dengan mangrove di semua stasiun. Selain itu, karakteristik lingkungan yang menentukan keberadaan fauna makrobentik $C$. carnifex adalah parameter $\mathrm{pH}$, dimana semakin tinggi konsentrasi $\mathrm{pH}$, maka kepadatan $C$. carnifex semakin menurun. Selain itu, karakteristik lingkungan yang menentukan keberadaan fauna makrobentik S. cucculata, M. latifrons dan A. scripta ditentukan oleh parameter DO dan salinitas yakni semakin rendah konsentrasi DO dan salinitas, maka kepadatan S. cucculata, M. latifrons maupun A. scripta akan semakin tinggi.
\end{abstract}

Kata kunci: Ekologi perairan, reboisasi mangrove, karakteristik lingkungan, fauna makrobentik, Kepulauan Seribu

\begin{abstract}
Macrobenthic fauna is often used as a bioindicator of environmental quality. However, information about the environmental characteristics and the existence of
\end{abstract}


macrobenthic fauna in the mangrove reforestation area is still very limited. The study of the profile of the Seribu Island mangrove reforestation area based on the characteristics of the macrobenthic environment and fauna was carried out in March 2014. The aim of this study is to determine the ecological conditions of the waters around the Seribu Island mangrove reforestation area. To find out the relationship between environmental characteristics and macrobenthic fauna with observation stations carried out by statistics on Correspondence Analysis (CA), while the environmental characteristics that determine macrobenthic fauna and their relationships are carried out with Principal Component Analysis (PCA) statistics and simple linear regression. The results of the study show that the concentration of measured environmental characteristics is not very different between stations and does not exceed the quality standard threshold for marine life. Then the macrobenthic fauna found consisted of 6 species with the highest density at Station 3 $\left(05.00 \mathrm{ind} / \mathrm{m}^{2}\right)$ and the lowest at Station $1\left(02.00 \mathrm{ind} / \mathrm{m}^{2}\right)$. At Station 1 the $\mathrm{pH}$ and temperature concentration is very high, while Station 2 and 3 have high salinity concentrations. Macrobenthic fauna Atilia (Columbella) scripta, Metopograpsus latifrons, Littoraria scabra, Saccostrea cucculata, and Cardisoma carnifex can be associated with mangroves at all stations. In addition, the environmental characteristics that determine the presence of C. carnifex macrobenthic fauna are $\mathrm{pH}$ parameters, where the higher the $\mathrm{pH}$ concentration, the lower the density of $C$. carnifex. Then the environmental characteristics that determine the presence of the macrobenthic fauna of $S$. cucculata, $M$. latifrons and A. scripta are determined by DO (Dissolved Oxygen) and salinity parameters namely the lower DO (Dissolved Oxygen) concentration and salinity, the higher the density of $S$. cucculata, M. latifrons and A. scripta.

Keywords: Aquatic ecology, mangrove reforestation, environmental characteristics, macrobenthic fauna, Seribu Island

\section{PENDAHULUAN}

Kepulauan Seribu merupakan salah satu kabupaten di Provinsi DKI Jakarta yang berada pada koordinat $5^{\circ} 10^{\prime} 00^{\prime \prime}-5^{\circ} 57^{\prime} 00^{\prime \prime}$ Lintang Selatan dan $106^{\circ} 19^{\prime} 30^{\prime \prime}-106^{\circ} 44^{\prime} 50^{\prime \prime}$ Bujur Timur, dimana geografinya tergolong dataran rendah (rata-rata ketinggiannya $\pm 1 \mathrm{~m}$ di atas permukaan laut), luasnya mencapai $8.70 \mathrm{~km}^{2}$, memiliki 110 pulau, bagian Utara berbatasan dengan Selat Sunda/Laut Jawa, Timur berbatasan dengan Laut Jawa, Selatan berbatasan dengan Kota Administrasi Jakarta Utara/Jakarta Barat/Kabupaten Tangerang dan Barat berbatasan dengan Laut Jawa/Selat Sunda (BPS Kepulauan Seribu, 2018). Menurut Kemhut (2012) Kepulauan Seribu adalah salah satu kawasan konservasi yang barbasis perairan laut di Indonesia (Taman Nasional Kepulauan Seribu/TNKS), dimana mempunyai nilai konservasi yang tinggi terhadap kelimpahan maupun keragaman jenis biota laut serta ekosistemnya yang unik dan khas (Natsir dan Dewi, 2015), sehingga menjadi salah satu destinasi bagi wisatawan lokal maupun mancanegara (Salim dan Hasanudin, 2016).

Mangrove adalah hutan pantai yang ditemukan di muara terlindung dan di sepanjang tepian sungai serta laguna di daerah tropis dan subtropis (Maiti dan Chowdhury, 2013), dimana di Indonesia, hutan mangrovenya terdapat di seluruh pantai dan tumbuh berkembang pada lokasi yang mempunyai hubungan pengaruh pasang surut air laut (Anwar dan Gunawan, 2006), sehingga komposisi jenis mangrovenya bervariasi dari satu pulau ke pulau yang lain (Kusmana, 2011) dan paling sedikitnya terdapat 38 spesies mangrove sejati teridentifikasi di Indonesia (Brown, 2007) yang menjadikan Indonesia sebagai habitat penting bagi mangrove dunia (Ilman et al., 2016). Namun, penggundulan hutan mangrove di Indonesia sangat tinggi (Murdiyarso et al., 2015). Penyebab utamanya adalah 
budidaya (akuakultur) dan perkebunan kelapa sawit (Giri et al., 2008; Basyuni et al., 2015; Richards dan Friess, 2016), sehingga Indonesia kehilangan lebih dari 1.2 Mha hutan mangrovenya (FAO, 2007).

Diberbagai tempat perusakan dan degradasi habitat mangrove, kini telah berupaya dilakukan kegiatan konservasi dan rehabilitasi mangrove (Alfaro, 2010) termasuk di Indonesia dan Kepulauan Seribu. Hal ini dilandasi oleh pentingnya hutan mangrove bagi lingkungan sekitar, baik itu sebagai penyedia makanan, tempat pembesaran maupun perlindungan bagi ikan, invertebrata, mamalia serta burung (Primavera, 1998; Robertson dan Duke, 1987; Sasekumar et al., 1992). Selain itu, juga dilandasi oleh karena mangrove dapat melindungi pesisir dari hantaman badai dan abrasi, menyimpan karbon, mendukung perikanan tangkap, menyediakan kayu, meningkatkan kualitas air hingga dapat memberikan kesempatan untuk rekreasi/pariwisata (Ewel et al., 1998; Barbier et al., 2011; Lee et al., 2014). Mengingat pentingnya hutan mangrove bagi lingkungan pesisir dan laut, kemudian tingkat kehadiran fauna bentik dapat dijadikan sebagai kriteria utama dalam menilai suatu keberhasilan rehabilitasi pantai (Field, 1998; Teal dan Weishar, 2005) serta masih minimnya kajian-kajian yang berkaitan dengan pasca reboisasi mangrove di Kepulauan Seribu, sehingga kajian di kawasan reboisasi mangrove Kepulauan Seribu berdasarkan karakteristik lingkungan dan fauna makrobentik sangat perlu dilakukan. Hal ini bertujuan untuk mengetahui kondisi ekologi perairan Kepulauan Seribu pasca dilakukan rehabilitasi mangrove yang berdasarkan karakteristik lingkungan dan keberadaan fauna makrobentiknya.

\section{METODE PENELITIAN}

\section{Waktu dan Tempat Penelitian}

Kajian dilaksanakan pada bulan Maret 2014 di kawasan reboisasi mangrove Kabupaten Kepulauan Seribu Provinsi Daerah Khusus Ibukota (DKI) Jakarta. Stasiun 1 berada di Pulau Pramuka, Stasiun 2 di Pulau Panggang dan Stasiun 3 di Pulau Karya (Gambar $1)$.

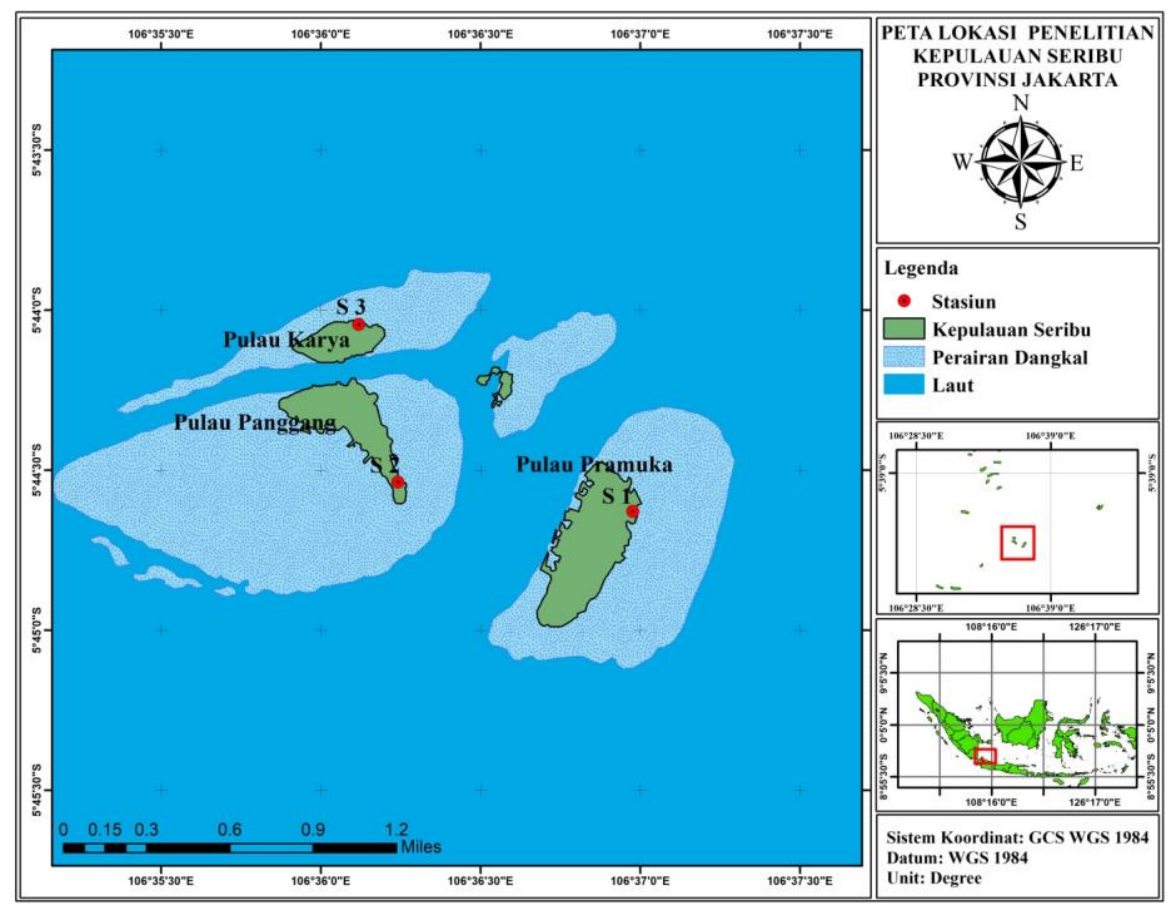

Gambar 1. Peta lokasi penelitian 


\section{Alat dan Bahan Penelitian}

Alat yang digunakan dalam penelitian ini adalah rol meter, buku identifikasi siput dan kerang (Dharma, 1988; Dolorosa dan Dangan-Galon, 2014; Zvonareva et al., 2015; Zvonareva dan Kantor, 2016; Kantharajan et al., 2017; Jeeva et al., 2018; Yadav et al., 2019; WoRMS, 2020), buku identifikasi kepiting brachyura $\mathrm{Ng}$ et al. (2008), data sheet, kamera, GPS Garmin 62 series, alat tulis, kantong plastik polyethylene, water quality meter (suhu, salinitas, $\mathrm{pH}$ ) dan cool box. Sementara bahan yang digunakan adalah alkohol $70 \%$ untuk pengawetan fauna makrobentik dan aquades untuk mengkalibrasi alat kualitas air.

\section{Pengumpulan Data Karakteristik Lingkungan}

Pengukuran karakteristik lingkungan dilakukan dengan cara in situ yaitu mengambil contoh air pada masingmasing stasiun pengamatan. Parameter karakteristik lingkungan yang diukur meliputi suhu perairan, $\mathrm{pH}$ dan salinitas dengan menggunakan water quality meter. Sementara parameter oksigen terlarut (DO) menggunakan data sekunder.

\section{Pengumpulan Data Fauna Makro- bentik}

Data fauna makrobentik di kawasan reboisasi mangrove Kepulauan seribu dikumpulkan dengan membuat transek garis dan plot yang ditarik dari titik acuan (tegakan mangrove terluar) dan tegak lurus garis pantai sampai ke daratan, kemudian transek garis tersebut dibuat petak-petak contoh (plot) dengan ukuran $10 \times 10 \mathrm{~m}$ dan di dalamnya dibuat plot kecil (sub plot) yang berukuran $1 \mathrm{x} 1$ m (Ernanto et al., 2010) sebanyak 5 plot. Tiap stasiun terdiri dari 3 plot dan tiap plot terdiri dari 5 sub plot, sehingga jumlah sub plot keseluruhannya adalah 45.

\section{Kepadatan Fauna Makrobentik}

Analisis kepadatan fauna makrobentik di kawasan reboisasi mangrove
Kepulauan Seribu mengacu pada Odum (1971), Southwood (1978), Brower dan Zar (1984) serta Krebs (1989).

\section{Keterkaitan Karakteristik Lingkungan dan Fauna Makrobentik dengan Stasiun Pengamatan}

Konektivitas (keterkaitan) antara karakteristik lingkungan dan fauna makrobentik dengan stasiun pengamatan di kawasan reboisasi mangrove Kepulauan Seribu dilakukan dengan analisis statistik Correspondence Analysis (CA) menggunakan software SPSS v19.

\section{Karakteristik Lingkungan Penentu Fauna Makrobentik dan Hubungan- nya}

Untuk mengetahui karakteristik lingkungan yang menentukan distribusi dan kepadatan fauna makrobentik di kawasan reboisasi mangrove Kepulauan Seribu digunakan analisis statistik multivariabel yang didasarkan pada Principal Component Analysis (PCA) menggunakan software SPSS v19, sedangkan untuk mengetahui hubungan karakteristik lingkungan dan fauna makrobentiknya dilakukan menggunakan regresi linier sederhana (Purnami et al., 2010; Choirudin et al., 2014; Hasby et al., 2014; Mushthofa et al., 2014; Pamuji et al., 2015; Wahyuningrum et al., 2016; Mustofa, 2018)

\section{HASIL DAN PEMBAHASAN}

\section{Karakteristik Lingkungan}

Tabel 1 memperlihatkan bahwa karakteristik lingkungan yang diukur di kawasan reboisasi mangrove Kepulauan Seribu tidak begitu berbeda antar stasiunnya. Hal ini karena letak geografis pulau (stasiun pengamatan) yang tidak terlalu jauh jaraknya. Selain itu, Tabel 1 juga memperlihatkan bahwa parameterparameter yang diukur tidak melebihi ambang batas baku mutu untuk biota laut, sehingga baik itu mangrove maupun fauna makrobentiknya dapat mentolerir untuk kelangsungan hidup mereka. 
Nobi et al. (2010) menyatakan bahwa kualitas air dan sedimen sangat penting untuk kelangsungan hidup dan kesejahteraan keanekaragaman hayati, terutama di daerah pesisir dan muara. Hal ini karena lingkungan intertidal mangrove merupakan lingkungan yang dinamis, baik itu secara fisik maupun geologis (Alongi, 2015), sehingga ekosistem mangrove menjadi rentan terhadap pengaruh lingkungan (Ghosh,
2011), kemudian Saintilan et al., (2014) menyatakan bahwa suhu merupakan faktor pembatas yang utama bagi mangrove karena memberikan penjelasan yang korelatif terhadap penyebarannya (Osland et al., 2013). Selanjutnya, Nguyen et al. (2015) menyatakan bahwa salinitas adalah salah satu ciri lingkungan yang mendefinisikan habitat mangrove, apakah berkisar antara air tawar ataupun hypersaline.

Tabel 1. Karakteristik lingkungan di kawasan reboisasi mangrove Kepulauan Seribu

\begin{tabular}{ccccc}
\hline \multirow{2}{*}{ Stasiun } & \multicolumn{4}{c}{ Kualitas Air } \\
\cline { 2 - 5 } & Suhu $\left({ }^{\circ} \mathbf{C}\right)$ & Salinitas (\%o) & pH & ${ }^{*}$ DO \\
\hline 1 & 32 & 30 & 7.7 & ${ }^{\mathrm{a}} 6.7$ \\
2 & 31 & 33 & 6.6 & ${ }^{\mathrm{b}} 7.0$ \\
3 & 30 & 31 & 7.0 & ${ }^{\mathrm{b}} 6.0$ \\
Baku mutu MNLH & $\mathbf{2 8}-\mathbf{3 2}$ & $\mathbf{s} / \mathbf{d ~ 3 4}$ & $\mathbf{7 - 8 . 5}$ & $>\mathbf{5}$ \\
$(\mathbf{2 0 0 4 )}$ & & &
\end{tabular}

*Data sekunder, ${ }^{\mathrm{a}}$ Faiqoh et al. (2015), ${ }^{\mathrm{b}}$ Riani et al. (2017)

Tabel 2. Distribusi fauna makrobentik di kawasan reboisasi mangrove Kepulauan Seribu

\begin{tabular}{|c|c|c|c|c|c|}
\hline \multirow{2}{*}{ Spesies } & \multirow{2}{*}{ Stasiun } & \multirow{2}{*}{ Lokasi } & \multicolumn{3}{|c|}{ Plot } \\
\hline & & & 1 & 2 & 3 \\
\hline $\begin{array}{l}\text { Atilia (Columbella) } \\
\text { scripta }\end{array}$ & & & & & \\
\hline $\begin{array}{l}\text { Littoraria scabra } \\
\text { Nerita albicilla }\end{array}$ & 1 & Pramuka & + & + & + \\
\hline $\begin{array}{l}\text { Cardisoma carnifex } \\
\text { Metopograpsus latifrons }\end{array}$ & & & + & & \\
\hline Saccostrea cucculata & & & + & + & \\
\hline $\begin{array}{l}\text { Atilia (Columbella) } \\
\text { scripta }\end{array}$ & & & + & & \\
\hline $\begin{array}{l}\text { Littoraria scabra } \\
\text { Nerita albicilla }\end{array}$ & 2 & Panggang & + & + & + \\
\hline Cardisoma carnifex & & & + & & \\
\hline Metopograpsus latifrons & & & & + & \\
\hline Saccostrea cucculata & & & + & & + \\
\hline $\begin{array}{l}\text { Atilia (Columbella) } \\
\text { scripta }\end{array}$ & & & & + & \\
\hline $\begin{array}{l}\text { Littoraria scabra } \\
\text { Nerita albicilla }\end{array}$ & 3 & Karya & + & + & $\begin{array}{l}+ \\
+\end{array}$ \\
\hline $\begin{array}{l}\text { Cardisoma carnifex } \\
\text { Metopograpsus latifrons }\end{array}$ & & & + & & \\
\hline Saccostrea cucculata & & & & + & \\
\hline
\end{tabular}




\section{Distribusi dan Kepadatan Fauna Ma- krobentik}

Fauna makrobentik yang ditemukan di kawasan reboisasi mangrove Kepulauan Seribu terdiri dari 3 spesies gastropoda (Atilia (Columbella) scripta, Littoraria scabra dan Nerita albicilla), 2 spesies kepiting brachyura (Cardisoma carnifex dan Metopograpsus latifrons) dan 1 spesies bivalva (Saccostrea cucculata) (Tabel 2).

Menurut Macintosh et al. (2002) keragaman vegetasi mangrove berkorelasi positif terhadap keragaman fauna terkait, dimana dalam indeks tegakan mangrove yang dewasa terdapat keanekaragaman fauna invertebrata yang lebih tinggi dibandingkan dengan tegakan mangrove yang baru ditanam, kemudian menurut Skilleter (1996), Skilleter dan Warren (2000) maupun Bosire et al. (2004) komposisi spesies, keanekaragaman, biomassa maupun kelimpahan invertebrata akan berubah apabila ada gangguan, eksploitasi serta berada di area rehabilitasi mangrove.

Selain itu, Tabel 2 juga memperlihatkan bahwa gastropoda $L$. scabra dan kepiting brachyura $C$. carnifex ditemukan merata di semua stasiun. Hal ini mengindikasi bahwa $L$. scabra dan C. carnifex memiliki toleransi yang sangat luas di kawasan reboisasi mangrove Kepulauan Seribu. Menurut Chen et al. (2007) gastropoda famili
Littoriinidae lebih representatif pada mangrove muda yang baru direhabilitasi, sedangkan kepiting C. carnifex ditemukan berbagi tempat dengan kepiting Neosarmatium meinerti, Chiromantes ortmanni, C. eulimene, Uca annulipes, $\quad U$. inversa, ikan Periophthalmus spp. dan spesies ikan lainnya di rawa-rawa mangrove Afrika Timur (Micheli et al., 1991; Colombini et al., 1995; Hartnoll et al,. 2002; Skov et al., 2002).

Kepadatan fauna makrobentik memperlihatkan hasil yang bervariasi, dimana rata-rata kepadatan tertingginya berada di Stasiun $3\left(05.00 \mathrm{ind} / \mathrm{m}^{2}\right)$ dan terendahnya di Stasiun $1\left(02.00 \mathrm{ind} / \mathrm{m}^{2}\right)$ (Tabel 3). Menurut Suratissa dan Rathnayake (2017) gastropoda laut ditemukan di berbagai habitat seperti pantai berpasir, pantai berbatu, hutan mangrove dan daerah berlumpur, kemudian Bolam et al. (2002) menyatakan bahwa keadaan substrat yang mengandung lumpur, memiliki kandungan bahan organik yang tinggi, sehingga merupakan habitat yang sesuai bagi gastropoda. Selanjutnya Alfaro (2006) menyatakan bahwa karakteristik substrat sangat penting bagi komunitas fauna makrobentik, hal ini karena strategi makanan mereka sangat menyesuaikan dengan jenis sedimen/substrat mangrovenya.

Tabel 3. Kepadatan fauna makrobentik di kawasan reboisasi mangrove Kepulauan Seribu

\begin{tabular}{ccccc}
\hline No & Stasiun & Substrat & Jumlah Individu & $\begin{array}{c}\text { Kepadatan } \\
\left(\mathbf{i n d} / \mathbf{m}^{2}\right)\end{array}$ \\
\hline 1 & 1.1 & Pasir & 35 & 02.00 \\
2 & 1.2 & Berlumpur & 26 & 02.00 \\
3 & 1.3 & & 43 & 03.00 \\
\hline \multicolumn{7}{r}{ Rata-Rata } & & $\mathbf{3 5} \pm \mathbf{0 8 . 5 0}$ & $\mathbf{0 2 . 0 0 \pm 0 0 . 5 8}$ \\
\hline 4 & 2.1 & Pasir & 48 & 03.00 \\
5 & 2.2 & 62 & 04.00 \\
6 & 2.3 & Berlumpur & 60 & 04.00 \\
\hline \multicolumn{7}{r}{ Rata-Rata } & & $\mathbf{5 7 \pm 0 7 . 5 7}$ & $\mathbf{0 4 . 0 0 \pm 0 0 . 5 8}$ \\
\hline 7 & 3.1 & 24 & 02.00 \\
8 & 3.2 & Lumpur & 75 & 05.00 \\
9 & 3.3 & Berpasir & 116 & 08.00 \\
& Rata-Rata & & $\mathbf{7 2 \pm 4 6 . 0 9}$ & $\mathbf{0 5 . 0 0 \pm 0 3 . 0 0}$ \\
\hline
\end{tabular}


Selain itu, Berti et al. (2008) menyatakan bahwa kepiting brachyura merupakan fauna makrobentik yang dominan di darat dan pinggiran pesisir ekosistem mangrove Indo-Pasifik (Sesarmidae dan Gecarcinidae), dimana aktivitasnya sangat berperan dalam keberlangsungan rantai makanan dan dikategorikan sebagai keystone species (Viswanathan et al., 2013). Hal ini disebabkan karena feses yang dikeluarkan kepiting brachyura sangat kaya akan nutrisi, kemudian feses tersebut digunakan oleh biota kecil lainnya sebagai pakan alami. Selain itu, serasah mangrove yang dicabik-cabik oleh kepiting brachyura (tidak dimakan) juga akan menjadi pakan bagi biota lainnya (Anggraeni et al., 2015).

\section{Keterkaitan Karakteristik Lingkungan dan Fauna Makrobentik dengan Stasiun Pengamatan}

Gambar 2 memperlihatkan bahwa pada Stasiun 1 lebih dicirikan oleh tingginya konsentrasi $\mathrm{pH}$ dan suhu perairan, sedangkan Stasiun 2 dan 3 dicirikan oleh tingginya konsentrasi salinitas. Tingginya $\mathrm{pH}$ perairan di Stasiun 1 mengindiksikan bahwa lokasi tersebut memiliki kandungan bahan organik yang rendah, sehingga menyebabkan kepadatan fauna makrobentiknya juga rendah. Hal ini sesuai dengan hasil kajian bahwa kepadatan fauna makrobentik di Stasiun 1 lebih rendah dibandingkan dengan stasiun lainnya (Tabel 3).

Menurut Supriyantini et al. (2017) tingginya nilai TOM (Total Organic Matter) akan mengurangi konsentrasi $\mathrm{pH}$, kemudian tingginya suhu perairan di Stasiun 1 mengindikasikan bahwa metabolisme biota perairannya sangat tinggi dan konsentrasi oksigen terlarutnya (DO) juga rendah. Hadiputra dan Damayanti (2013) menyatakan bahwa meningkatnya laju metabolisme akan menyebabkan peningkatan kebutuhan oksigen, sementara naiknya temperatur akan menyebabkan oksigen terlarut menjadi turun, sehingga organisme air mengalami kesulitan dalam berespirasi.

$$
\text { Selanjutnya }
$$

Gambar

3 memperlihatkan bahwa fauna makrobentik A. scripta, M. latifrons, $L$. scabra, S. cucculata dan C. carnifex berasosiasi dengan semua stasiun. Ini mengindikasikan bahwa makrobentik tersebut sangat menyukai habitat yang memiliki substrat pasir berlumpur maupun lumpur berpasir. Selain itu, mereka juga berkembang dan tumbuh pada kisaran suhu $30-32^{\circ} \mathrm{C}$, salinitas 30 - 33\%, pH 6.6 - 7.7 dan oksigen terlarut (DO) $6.0-7.0$ (Tabel 1). Menurut Pagliosa et al. (2016) fauna bentik yang mengkoloni tanah mangrove dapat beradaptasi dengan baik pada kondisi yang banyak tekanan, sehingga toleran terhadap variasi kesuburan, pengeringan, konsentrasi oksigen tanah yang rendah maupun kandungan bahan organik yang tinggi (Cannicci et al., 2008; Lee, 2008; Nagelkerken et al., 2008).

Nordhaus et al. (2009) menyatakan bahwa invertebrata bentik merupakan kelompok penting dalam jaring-jaring makanan dan sangat mempengaruhi aliran energi di ekosistem mangrove. Hal ini disebabkan karena mereka dijadikan sumber makanan bagi ikan di saat pasang berlangsung (Wilson, 1989; Sheaves dan Molony, 2000). Menurut Dittmann (2000) kelimpahan dan keanekaragaman spesies makro maupun mesofauna bentik tertingginya berada di zona intertidal bagian tengah, sedangkan terendahnya berada di zona intertidal bagian bawah.

Selain itu, fauna makrobentik juga dapat memodifikasi struktur fisik maupun vegetasi mangrove melalui aktivitas penggalian dan memakan alga yang ada di propagul, daun serta batang tanaman mangrove (Smith, 1987; Smith et al., 1991). Di Indonesia, fauna makrobentiknya terdiri dari 50 spesies gastropoda, 6 spesies bivalva dan 34 spesies krustasea (Kusmana, 2011). 


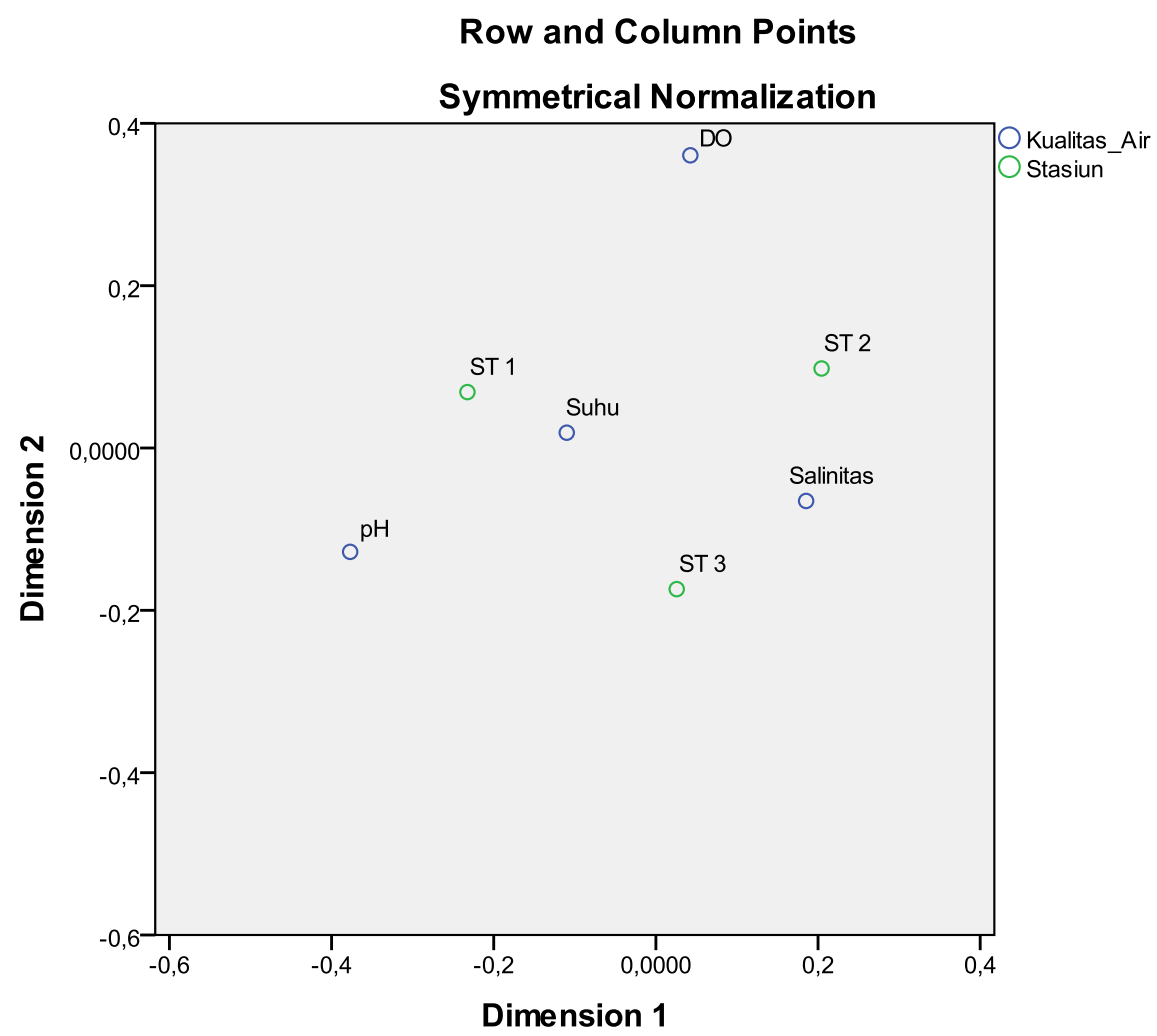

Gambar 2. Keterkaitan karakteristik lingkungan di setiap stasiun pengamatan

\section{Row and Column Points}

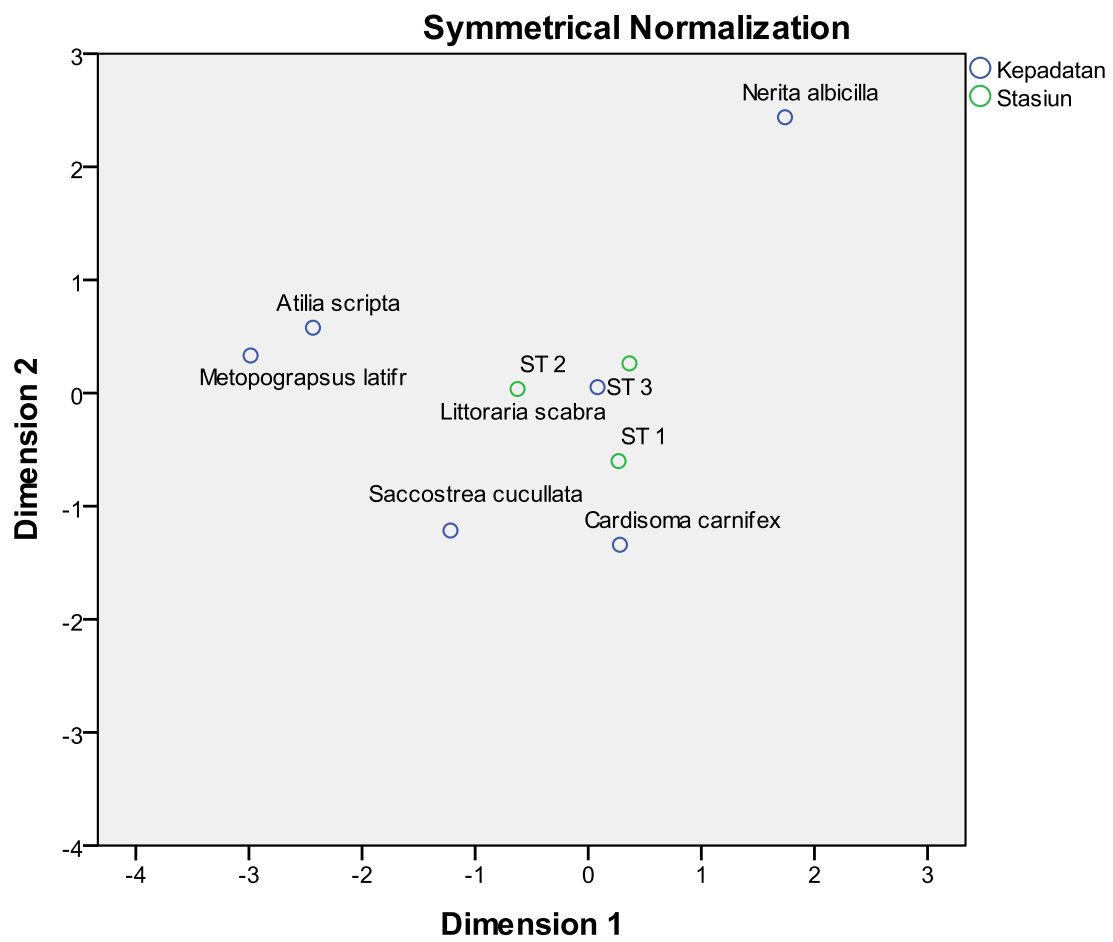

Gambar 3. Keterkaitan fauna makrobentik di setiap stasiun pengamatan 


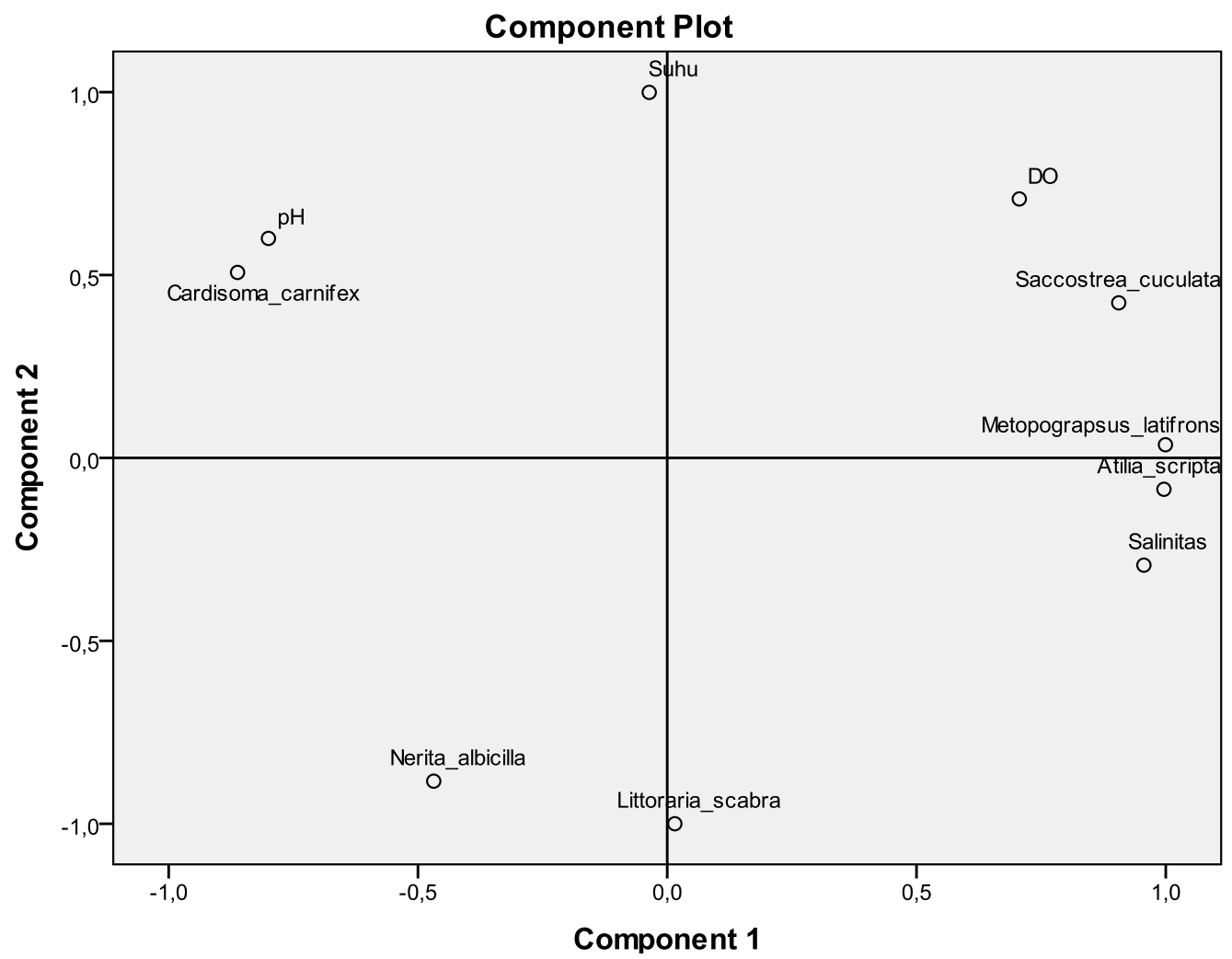

Gambar 4. Karakteristik lingkungan yang menentukan keberadaan fauna makrobentik di kawasan reboisasi mangrove Kepulauan Seribu

\section{Karakteristik Lingkungan Penentu Fauna Makrobentik dan Hubungannya}

Karakteristik lingkungan yang menentukan keberadaan fauna makrobentik di kawasan reboisasi mangrove Kepulauan Seribu terbagi atas 2 kelompok (Gambar 4). Untuk kelompok pertama fauna makrobentik $C$. carnifex sangat ditentukan oleh parameter $\mathrm{pH}$, dimana semakin tinggi konsentrasi $\mathrm{pH}$, maka kepadatan $C$. carnifex semakin menurun (Gambar 5). Menurut Rukminasari et al. (2014) berubahnya nilai $\mathrm{pH}$ akan menimbulkan perubahan dan ketidakseimbangan kadar $\mathrm{CO}_{2}$ yang dapat membahayakan kehidupan biota laut, kemudian Hamzah dan Setiawan (2010) menyatakan bahwa faktor yang mempengaruhi rendahnya nilai $\mathrm{pH}$ adalah proses reaksi reduksi dan oksidasi yang terjadi pada sedimen, dimana organisme pengurai melepaskan asam untuk melakukan akumulasi dekomposisi bahan organik (Gopinath et al., 2010). Selanjutnya, pada kelompok kedua, makrobentik S. cucculata, $M$. latifrons dan A. scripta ditentukan oleh parameter DO dan salinitas (Gambar 4), dimana semakin rendah konsentrasi DO dan salinitas, maka kepadatannya juga semakin tinggi (Gambar 5), sehingga mengindikasikan bahwa fauna makrobentik S. cucculata, M. latifrons maupun A. scripta sangat menyukai lingkungan yang bersalintas dan DO rendah. Sriyaraj dan Shutes (2001) menyatakan bahwa dalam kolom air, perubahan kondisi hidrologi dapat memodifikasi atau mengubah sifat geokimia sedimen maupun infauna dan flora intertidal, kemudian Pratiwi (2012) menyatakan bahwa setiap kepiting memiliki kemampuan toleransi terhadap kondisi lingkungan tertentu. 

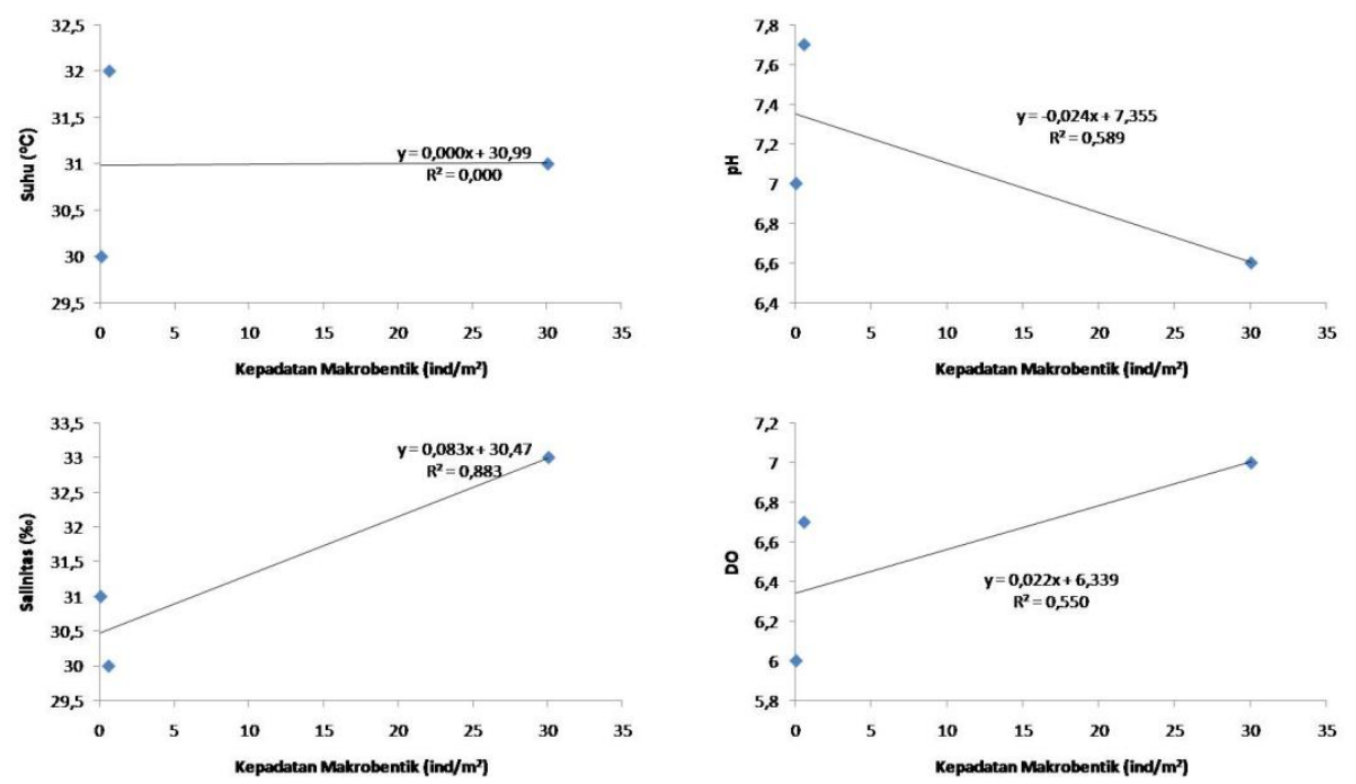

Gambar 5. Hubungan karakteristik lingkungan dan fauna makrobentik di kawasan reboisasi mangrove Kepulauan Seribu

\section{KESIMPULAN}

Karakteristik lingkungan yang diukur tidak begitu berbeda antar stasiunnya dan juga tidak melebihi ambang baku mutu biota laut, kemudian fauna makrobentik yang ditemukan terdiri dari 3 spesies gastropoda, 2 spesies kepiting brachyura dan 1 spesies bivalva dengan gastropoda $L$. scabra dan kepiting brachyura $C$. carnifex ditemukan merata di semua stasiun pengamatan. Selanjutnya kepadatan fauna makrobentik tertingginya berada di Stasiun $3\left(05.00 \mathrm{ind} / \mathrm{m}^{2}\right)$ dan terendahnya di Stasiun $1 \quad\left(02.00\right.$ ind $\left./ \mathrm{m}^{2}\right)$. Untuk Stasiun 1 dicirikan oleh konsentrasi $\mathrm{pH}$ dan suhu yang tinggi, sedangkan Stasiun 2 maupun 3 dicirikan oleh salinitas. Fauna makrobentik A. scripta, $M$. latifrons, L. scabra, S. cucculata dan $C$. carnifex berasosiasi dengan mangrove yang ditanam pada semua stasiun. Selain itu, karakteristik lingkungan yang menentukan keberadaan fauna makrobentik di kawasan reboisasi mangrove Kepulauan Seribu terbagi atas 2 kelompok, dimana distribusi dan kepadatan fauna makrobentik $C$. carnifex sangat ditentukan oleh parameter $\mathrm{pH}$ yakni semakin tinggi konsentrasi $\mathrm{pH}$, maka kepadatan $C$. carnifex semakin menurun. Selanjutnya, distribusi dan kepadatan makrobentik S. cucculata, $M$. latifrons maupun A. scripta ditentukan oleh parameter DO dan salinitas yakni semakin rendah konsentrasi DO dan salinitas, maka kepadatan S. cucculata, $M$. latifrons maupun A. scripta akan semakin tinggi.

\section{DAFTAR PUSTAKA}

Alfaro, A. C. (2006). Benthic macroinvertebrate community composition within a mangrove/seagrass estuary in Northern New Zealand. Estuarine, Coastal and Shelf Science. 66 (12): $97-110$.

Alfaro, A. C. (2010). Effects of mangrove removal on benthic communities and sediment characteristics at Mangawhai Harbour, Northern New Zealand. ICES Journal of Marine Science. 67(6): 1087 - 1104.

Alongi, D. M. (2015). The impact of climate change on mangrove forests. Current Climate Change Reports. 1(1): $30-39$.

Anggraeni, P., Elfidasari, D., Pratiwi, R. (2015). Sebaran kepiting (brachyura) di Pulau Tikus, 
Gugusan Pulau Pari, Kepulauan Seribu. Prosiding Seminar Nasional Masyarakat Biodiversitas Indonesia. 1(2): 213 - 221.

Anwar, C., Gunawan, H. (2006). Peranan ekologis dan sosial ekonomis hutan mangrove dalam mendukung pembangunan wilayah pesisir. Dalam: Prosiding Ekspose HasilHasil Penelitian: Konservasi dan Rehabilitasi Sumberdaya Hutan. 20 September 2006. Padang, Indonesia.

Barbier, E. B., Hacker, S. D., Kennedy, C., Koch, E. W., Stier, A. C., Silliman, B. R. (2011). The value of estuarine and coastal ecosystem services. Ecological Monographs. 81(2): 169 - 193.

Basyuni, M., Putri, L. A. P., Murni, M. B. (2015). Implication of land-use and land-cover change into carbon dioxide emissions in Karang Gading and Langkat Timur wildlife reserve, North Sumatra, Indonesia. Manajemen Hutan Tropika. 21(1): 25 - 35 .

Berti, R., Cannicci, S., Fabbroni, S., Innocenti, G. (2008). Notes on the structure and the useof Neosarmatium meinerti and Cardisoma carnifex burrows in a Kenyan mangrove swamp (Decapoda Brachyura). Ethology Ecology and Evolution. 20(2): 101 -113 .

Bolam, S. G., Fernandes, T. F., Huxham, M. (2002). Diversity, biomass, and ecosystem processes in the marine benthos. Ecological Monographs. 72(4): $599-615$.

Bosire, J. O., Dahdouh-Guebas, F., Kairo, J. G., Cannicci, S., Koedam, N. (2004). Spatial variations in macrobenthic fauna recolonisation in a tropical mangrove bay. Biodiversity and Conservation. 13(6): 1059 - 1074.

[BPS] Badan Pusat Statistik Kabupaten Kepulauan Seribu. (2018). Kepulauan Seribu Dalam Angka 2018. Jakarta, Indonesia. 310 hal.
Brower, J. E., \& Zar, J. H. (1984). Field and Laboratory Methods for General Ecology Second Edition. Dubuque, IA : W.C. Brown Publishers.

Brown, B. 2007. Resilience Thinking Applied to the Mangroves of Indonesia. IUCN \& Mangrove Action Project. Yogyakarta, Indonesia. $53 \mathrm{p}$.

Cannicci, S., Burrows, D., Fratini, S., Smith, T. J., Offenberg, J., Dahdouh-Guebas, F. (2008). Faunal impact on vegetation structure and ecosystem function in mangrove forests: A review. Aquatic Botany. 89(2): 186 - 200.

Chen, G., Ye, Y., Lu, C. (2007). Changes of macro-benthic faunal community with stand age of rehabilitated Kandelia candel mangrove in Jiulongjiang Estuary, China. Ecological Engineering. 31(3): $215-224$.

Choirudin, I. R., Supardjo, M. N., Muskananfola, M. R. (2014). Studi hubungan kandungan bahan organik sedimen dengan kelimpahan makrozoobenthos di muara Sungai Wedung Kabupaten Demak. Management of Aquatic Resources. 3(3): 168 - 176.

Colombini, I., Bert, R., Ercolini, A., Nocita, A., Chelazzib, L. (1995). Environmental factors influencing the zonation and activity patterns of a population of Periophthalmus sobrinus Eggert in a Kenyan mangrove. Experimental Marine Biology and Ecology. 190(1): 135 $-149$.

Dharma, B. (1988). Siput dan Kerang Indonesia (Indonesian Shells). Jakarta, Indonesia.

Dittmann, S. (2000). Zonation of benthic communities in a tropical tidal flat of North-East Australia. Sea Research. 43(1): 33 - 51.

Dolorosa, R. G., Dangan-Galon, F. (2014). Species richness of bivalves and gastropods in Iwahig River-Estuary, Palawan, the Philippines. International Journal 
of Fisheries and Aquatic Studies. 2(1): $207-215$.

Ernanto, R., Agustriani, F., Aryawati, R. (2010). Struktur komunitas gastropoda pada ekosistem mangrove di muara Sungai Batang Ogan Komering Ilir Sumatera Selatan. Maspari. 1: 73 - 78.

Ewel, K. C., Twilley, R. R., Ong, J. E. (1998). Different kinds of mangrove forests provide different goods and services. Global Ecology and Biogeography Letters. 7(1): 83 - 94.

Faiqoh, E., Ayu, I. P., Subhan, B., Syamsuni, Y. F., Anggoro, A. W., Sembiring, A. (2015). Variasi geografik kelimpahan zooplankton di perairan terganggu, Kepulauan Seribu, Indonesia. Marine and Aquatic Sciences. 1: 19-22.

[FAO] Food and Agriculture Organization. (2007). The World's Mangroves 1980 - 2005: A Thematic Study Prepared in The Frameworkof The Global Forest Resources Assessment 2005. Roma, Itali.

Field, C. D. (1998). Rehabilitation of mangrove ecosystems: An overview. Marine Pollution Bulletin. 37(8-12): 383 - 392.

Ghosh, D. (2011). Mangroves: The most fragile forest ecosystem. Resonance. 16(1): 47 - 60 .

Giri, C., Zhu, Z., Tieszen, L. L., Singh, A., Gillette, S., Kelmelis, J. A. (2008). Mangrove forest distributions and dynamics (19752005) of the tsunami-affected region of Asia. Biogeography. 35(3): $519-528$.

Gopinath, A., Nair, S. M., Kumar, N. C., Jayalakshmi, K. V., \& Pamalal, D. (2010). A baseline study of trace metals in a coral reef sedimentary environment, Lakshadweep Archipelago. Environmental Earth Sciences. 59(6): 1245 - 1266.

Hadiputra, M. A., Damayanti, A. (2013). Kajian potensi makrozoobentos sebagai bioindikator pencemaran logam berat tembaga $(\mathrm{Cu})$ di kawasan ekosistem mangrove Wonorejo Pantai Timur Surabaya. Dalam: Prosiding Seminar Nasional Manajemen Teknologi XVIII. 27 Juli 2013. Surabaya, Indonesia. D-14-1 - D-14-8.

Hamzah, F., Setiawan, A. (2010). Akumulasi logam berat $\mathrm{Pb}, \mathrm{Cu}$, dan $\mathrm{Zn}$ di hutan mangrove Muara Angke, Jakarta Utara. Ilmu dan Teknologi Kelautan Tropis. 2(2): $41-52$.

Hartnoll, R. G., Cannicci, S., Emmerson, W. D., Fratini, S., Macia, A., Mgaya, Y., Porri, F., Ruwa, R. K., Shunula, J. P., Skov, M. W., Vannini, M. (2002). Geographic trends in mangrove crab abundance in East Africa. Wetlands Ecology and Management. 10(3): 203 - 213.

Hasby, M., Thamrin, Sukendi. (2014). Keberlanjutan biota Sungai Sail Kota Pekanbaru (studi kasus distribusi dan kelimpahan makrozoobenthos). Dinamika Pertanian. 29(3): 295 - 306.

Ilman, M., Dargusch, P., Dart, P., Onrizal. (2016). A historical analysis of the drivers of loss and degradation of Indonesia's mangroves. Land Use Policy. 54:448 - 459 .

Jeeva, C., Mohan, P. M., Sabith, K. K. D. B., Ubare, V. V., Muruganantham, M., Kumari, R. K. (2018). Distribution of gastropods in the intertidal environment of South, Middle and North Andaman Islands, India. Open Journal of Marine Science. 8: 173 - 195.

Kantharajan, G., Pandey, P. K., Krishnan, P., Samuel, V. D., Bharti, V. S., Purvaja, R. (2017). Molluscan diversity in the mangrove ecosystem of Mumbai, west coast of India. Regional Studies in Marine Science. 14: 102 - 111.

[Kemut] Kementerian Kehutanan. (2012). Informasi Taman Nasional Laut. Jakarta, Indonesia. 230 hal.

Krebs, C. J. (1989). Ecological Methodology. New York: 
University of British Columbia, Harper Collins Publishers.

Kusmana, C. (2011). Management of mangrove ecosystem in Indonesia. Pengelolaan Sumberdaya Alam dan Lingkungan. 1(2): 152 - 157.

Lee, S. Y. (2008). Mangrove macrobenthos: Assemblages, services and linkages. Sea Research. 59(1-2): 16-29.

Lee, S. Y. Primavera, J. H., DahdouhGuebas, F., McKee, K., Bosire, J. O., Cannicci, S., Diele, K., Fromard, F., Koedam, N., Marchand, C., Mendelssohn, I., Mukherjee, N., Record, S. (2014). Ecological role and services of tropical mangrove ecosystems: A reassessment. Global Ecology and Biogeography. 23(7): 726 - 743.

Macintosh, D. J., Ashtona, E. C., Havanon, S. (2002). Mangrove rehabilitation and intertidal biodiversity: A study in the Ranong Mangrove Ecosystem, Thailand. Estuarine, Coastal and Shelf Science. 55(3): 331 - 345.

Maiti, S. K., Chowdhury, A. (2013). Effects of anthropogenic pollution on mangrove biodiversity: A review. Environmental Protection. 4(12): $1428-1434$.

Micheli, F., Gherardi, F., Vannini, M. (1991). Feeding and burrowing ecology of two East African mangrove crabs. Marine Biology. 111: $247-254$.

[MNLH] Menteri Negara Lingkungan Hidup. (2004). Keputusan Menteri Negara Lingkungan Hidup Tentang Baku Mutu Air Laut Nomor 51. Jakarta, Indonesia.

Murdiyarso, D., Purbopuspito, J., Kauffman, J. B., Warren, M. W., Sasmito, S. D., Donato, D. C., Manuri, S., Krisnawati, H., Taberima, S., Kurnianto, S. (2015). The potential of Indonesian mangrove forests for global climate change mitigation. Nature Climate Change. 5: 1089 - 1092.

Mushthofa, A., Muskananfola, M. R., Rudiyanti, S. (2014). Analisis struktur komunitas makrozoobenthos sebagai bioindikator kualitas perairan Sungai Wedung Kabupaten Demak. Management of Aquatic Resources. 3(1): 81 - 88 .

Mustofa, A. (2018). Pengaruh total padatan tersuspensi terhadap biodiversitas makrozoobentos di pantai Telukawur Kabupaten Jepara. Disprotek. 9(1): 37 - 45.

Nagelkerken, I., Blaber, S. J. M., Bouillon, S., Green, P., Haywood, M., Kirton, L. G., Meynecke, J. O., Pawlik, J., Penrose, H. M., Sasekumar, A., Somerfield, P. J. (2008). The habitat function of mangroves for terrestrial and marine fauna: A review. Aquatic Botany. 89(2): 155 - 185.

Natsir, S. M., Dewi, K. T. (2015). Foraminifera bentik terkait dengan kondisi lingkungan perairansekitar Pulau Damar, Kepulauan Seribu. Geologi Kelautan. 13(3): 165 171.

Ng, P. K. L., Guinot, D., Davie, P. J. F. (2008). Systema brachyurorum: Part I. An annotated checklist of extant brachyuran crabs of the world. The Raffles Bulletin of Zoology. 17: 1- 286.

Nguyen, H. T., Stanton, D. E., Schmitz, N., Farquhar, G. D., Ball, M. C. (2015). Growth responses of the mangrove Avicennia marina to salinity: Development and function of shoot hydraulic systems require saline conditions. Annals of Botany. 115(3): 397 - 407.

Nobi, E. P., Dilipan, E., Thangaradjou, T., Sivakumar, K., Kannan, L. (2010). Geochemical and geostatistical assessment of heavy metal concentration in the sediments of different coastal ecosystems of Andaman Islands, India. Estuarine, Coastal and Shelf Science. 87(2): $253-264$.

Nordhaus, I., Hadipudjana, F. A., Janssen, R., Pamungkas, J. (2009). Spatio-temporal variation of macrobenthic communities in the 
mangrove-fringed Segara Anakan lagoon, Indonesia, affected by anthropogenic activities. Regional Environmental Change. 9(4): 291 $-313$.

Odum, E. P. (1971). Fundamentals of Ecology $3^{\text {rd }}$ Edition. W. B. Saunders Co. Philadelphia.

Osland, M. J., Enwright, N., Day, R. H., Doyle, T. W. (2013). Winter climate change and coastal wetland foundation species: Salt marshes vs. mangrove forests in the Southeastern United States. Global Change Biology. 19(5): 1482 1494.

Pagliosa, P. R., Oortman, M. S., Rovai, A. S., Soriano-Sierra, E. J. (2016). Is mangrove planting insufficient for benthic macrofaunal recoverywhen environmental stress is persistent? Ecological Engineering. 95: 290 - 301.

Pamuji, A., Muskananfola, M. R., A'in, C. (2015). Pengaruh sedimentasi terhadap kelimpahan makrozoobenthos di muara Sungai Betahwalang Kabupaten Demak. Saintek Perikanan. 10(2): 129 135.

Pratiwi, R. (2012). Jenis dan pola sebaran fauna Krustasea di padang lamun Pulau Tikus, Kepulauan Seribu. Oseanologi dan Limnologi di Indonesia. 38(1): 43 - 55.

Primavera, J. H. (1998). Mangroves as nurseries: Shrimp populations in mangrove and non-mangrove habitats. Estuarine, Coastal and Shelf Science. 46: 457 - 464.

Purnami, T. P., Sunarto, Setyono, P. (2010). Study of bentos community based on diversity and similarity index in Cengklik Dam Boyolali. Ekosains. 2(2): 50 - 65.

Riani, E., Johari, H. S., Cordova, M. R. (2017). Bioakumulasi logam berat kadmium dan timbal pada Kerang Kapak-Kapak di Kepulauan Seribu. Pengolahan Hasil Perikanan Indonesia. 20(1): 131 142.
Richards, D. R., Friess, D. A. (2016). Rates and drivers of mangrove deforestation in Southeast Asia, 2000-2012. Proceedings of the National Academy of Sciences. 113(2): 344 - 349 .

Robertson, A. I., Duke, N. C. (1987). Mangroves as nursery sites: Comparisons of the abundance and species composition of fish and crustaceans in mangroves and other nearshore habitats in tropical Australia. Marine Biology. 96(2): $193-205$.

Rukminasari, N., Nadiarti, Awaluddin, K. (2014). Pengaruh derajat keasaman $(\mathrm{pH})$ air laut terhadap konsentrasi kalsium dan laju pertumbuhan Halimeda sp. Torani. 24(1): $28-34$.

Saintilan, N., Wilson, N., Rogers, K., Rajkaran, A., Krauss, K. W. (2014). Mangrove expansion and salt marsh decline at mangrove poleward limits. Global Change Biology. 20(1): 147 - 157.

Salim, A. I., Hasanudin. (2016). Desain floating resort sebagai penunjang pariwisata di perairan Kepulauan Seribu. Teknik ITS. 5(2): G123 128.

Sasekumar, A., Chong, V. C., Leh, M. U., D’Cruz, R. (1992). Mangroves as a habitat for fish and prawns. Hydrobiologia. 247(1-3): 195 207.

Sheaves, M., Molony, B. (2000). Shortcircuit in the mangrove food chain. Marine Ecology Progress Series. 199: 97 - 109.

Skilleter, G. A. (1996). Validation of rapid assessment of damage in urban mangrove forests and relationships with molluscan assemblages. The Marine Biological Association of the United Kingdom. 76(3): $701-716$.

Skilleter, G. A., Warren, S. (2000). Effects of habitat modification in mangroves on the structure of mollusc and crab assemblages. Experimental Marine Biology and Ecology. 244: 107-129. 
Skov, M. W., Vannini, M., Shunula, J., Hartnoll, R., \& Cannicci, S. (2002). Quantifying the density of mangrove crabs: Ocypodidae and Grapsidae. Marine Biology. 141: $725-732$.

Smith, T. J. (1987). Seed predation in relation to tree dominance and distribution in mangrove forests. Ecology. 68(2): 266 - 273.

Smith, T. J., Boto, K. G., Frusher, S. D., Giddins, R. L. (1991). Keystone species and mangrove forest dynamics: The influence of burrowing by crabs on soil. Estuarine, Coastal and Shelf Science. 33(5): $419-432$.

Southwood, T. R. E. (1978). Ecological Methods. London, Inggris.

Sriyaraj, K., Shutes, R. B. E. (2001). An assessment of the impact of motorway runoff on a pond, wetland and stream. Environment International. 26(5-6): 433 - 439.

Supriyantini, E., Nuraini, R. A. T., \& Fadmawati, A. P. (2017). Studi kandungan bahan organik pada beberapa muara sungai di kawasan ekosistem mangrove, di wilayah pesisir pantai Utara Kota Semarang, Jawa Tengah. Buletin Oseanografi Marina. 6(1): 29 38.

Suratissa, D. M., Rathnayake, U. (2017). Effect of pollution on diversity of marine gastropods and its role in trophic structure at Nasese Shore, Suva, Fiji Islands. Asia-Pacific Biodiversity. 10: 192 - 198.

Teal, J. M., Weishar, L. (2005). Ecological engineering, adaptive management, and restoration management in Delaware Bay salt marsh restoration. Ecological Engineering. 25(3): $304-314$.

Viswanathan, C., Suresh, T. V., Elumalai, V., Pravinkumar, M., Raffi, S. M. (2013). Recurrence of a marine brachyuran crab, Parapanope euagora (Crustacea: Decapoda: Brachyura: Galenidae) from East Coast of India. Arthropods. 2(2): 75 - 79 .
Wahyuningrum, E. S., Muskananfola, M. R., Suryanto, A. (2016). Hubungan tekstur sedimen, bahan organik dengan kelimpahan biota makrozoobentos di perairan Delta Wulan, Kabupaten Demak. Management of Aquatic Resources. 5(1): $46-51$.

Wilson, K. A. (1989). Ecology of mangrove crabs: Predation, physical factors and refuges. Bulletin of Marine Science. 44(1): $263-273$.

[WoRMS] World Register of Marine Species. (2020). Diakses dari http://www.marinespecies.org/.

Yadav, R., Malla, P. K., Dash, D., Bhoi, G., Patro, S., \& Mohapatra, A. (2019). Diversity of gastropods and bivalves in the mangrove ecosystem of Paradeep, east coast of India: A comparative study with other Indian mangrove ecosystems. Molluscan Research. DOI: 10.1080/13235818.2019.1644701.

Zvonareva, S., Kantor, Y. (2016). Checklist of gastropod molluscs in mangroves of Khanh Hoa province, Vietnam. Zootaxa. 4162(3): $401-437$.

Zvonareva, S., Kantor, Y., Li, X., Britayev, T. (2015). Long-term monitoring of gastropoda (mollusca) fauna in planted mangroves in Central Vietnam. Zoological Studies. 54(1): $1-16$. 
